\title{
Practice of Metaterminographic Study in Russia
}

\author{
Marina V. Trossel* \\ Siberian Federal University \\ 79 Svobodny, Krasnoyarsk, 660041, Russia
}

Received 09.02.2018, received in revised form 16.04.2018, accepted 27.04.2018

Modern terminography in Russia is considered to be a separate complex discipline which comprises 3 sub-areas: history of terminography, metaterminography, practical terminography. The main peculiar feature of terminography, worth mentioning, is not only the value of its practical workdictionaries of special lexis, but also in the fact that this very science has the greatest number of deeper and wider interrelations with many other scientific disciplines and branches of industry. The present article describes metaterminology with its own subject and main aims of investigation, dwells on metaterminological studies in Russia, enumerating their strong and weak points.

Keywords: terminography, metaterminography, lexicography, terminological lexicography, dictionary.

DOI: 10.17516/1997-1370-0298.

Research area: linguistics.

\section{Introduction}

At present, there is a great number of native research works devoted to the problems of terminography and lexicographic modeling of different terminologies. Nevertheless, there are still a lot of lacunas in this field, and this article aims to describe some of the existing problems. Yet, first, general ideas connected with terminography and metaterminography will be presented.

"Terminography", as a term, has often been used interchangeably with the term "LSP lexicography". From this point of view, terminography is considered to be a part of lexicography, comprising both theoretical and practical fields. Theoretical lexicography, or metalexicography, deals with the elaboration of general typology of dictionaries; lexicographic rules such as lexical units selection principles, choice of definition types used in a dictionary, presentation of certain illustrative material along with grammatical and stylistic remarks, etymologic comments; investigation of lexicology and lexicography metalanguage; formation of lexicographic terminology; theoretical support of compiling thesaurus and computer dictionaries; and planning and organizing the work on compiling a dictionary among other areas.

The overarching subject of metalexicography is the development of principles and methods of dictionary compilation, while the core point is the study of dictionary types, their inner composition and the structure of the dictionary entry.

In the same way, the subject of theoretical terminography, or metaterminography (the latter term offered by M. Lukasik and used by the author

(C) Siberian Federal University. All rights reserved

* Corresponding author E-mail address: marinatrossel@gmail.com 
of this article as the most appropriate according to terminological principles), is the development of methodology and concrete methods of terminological dictionaries. Therefore, the main tasks are the development of classification principles and typology of terminological dictionaries, drafting the principles of inclusion of special lexical units in certain types of terminological dictionaries, etc.

The main reasons for the emergence of metaterminography are:

- appearance of concept of lexicographic parameter in scientific investigations connected with the development of dictionaries' typology,

- necessity for the generalization of the experience in the compilation of terminological dictionaries of different types (explanatory, translation, informative, etc.),

- consideration of terminological dictionaries as a special genre of scientific prose,

- computerization of terminographic work and the problems connected with the creation of computer dictionaries and terminology databases.

\section{History of Metaterminography}

In Russia, metaterminography became one of the branches of linguistics and terminology in 1970-s, when the centre of metalexicographic development moved from France to Russia. The works of such scholars as U.D. Apresyan, V.G. Gak, P.N. Denisov, U.N. Karaulov were of central importance in this transition. For example, U.N. Karaulov was the first to suggest the concept of lexicographic parameter, a notion that later became the basic point in theory of dictionary compilation. The author marked around 67 linguistic parameters that are to be mentioned in dictionaries of different types. Among these parameters are: word stress, spelling, pronunciation, information on the part of speech, information on grammatical form, word-building information, stylistic remark, etc.
In 1983 a work of A.Y. Shaikevich titled "The Problems of LSP lexicography" was published. It aimed to answer such important questions of metaterminography as: what lexical units should be included in a dictionary, what is the way for laying the material out, what is the best way to define terms, what is the best way for arranging various kinds of terminological dictionary, etc.

Later in 1986 a text-book titled "The Basis of Technical and Scientific Lexicography" by A.S. Gerd was released. In it, the author described the compilation principles for different terminological dictionaries, starting from the choice of resources, moving to the formation of glossary and touching the problem of terms interpretation.

In the same year S.V. Grinyov published his textbook "Introduction to Terminological Lexicography", which was another work of great importance for metaterminography. Inter alia, the work, elaborated on lexicographic parameters of terminological dictionaries, listed all possible elements of their macro- and micro-composition.

Actually, the period of the 1980-s is considered to be the pick of scientific surveys in the field of terminology. At different time periods classifying principles, that are still very important for metaterminography, were developed by the scholars mentioned above, and also by V.M. Leichik, Z.I. Komarova, M.M. Dubchinsky and some others. At that time hundreds of theses were annually defended. This period is also marked by two important events. The first one is a doctorate thesis by V.M. Leichik titled "The subject, methods and structure of terminological science" (1989) which marked the final scientific point necessary for separating terminological science as an independent complex discipline, while the second is the onset of the third period in the history of terminological science development that, unfortunately, is less prominent. Due to the economic situation in Russia at that time a 
number of scientific institutions were closed, some of the scientists emigrated, the number of scientific research works decreased greatly.

Further development of the science started only in the 1990-s. In that period some important works salient for metaterminography were published, including "The Basis of Terminography" (Marchuk, 1992) and "Introduction to Terminography” (Grinyov, 1993).

\section{Terminographic and Metaterminographic study}

\subsection{Typology of specialized dictionaries}

The importance of terminography is obvious, as its objective is to systemize, regulate and unify special lexical units of certain terminology and to disseminate such units in product as a dictionary of certain type: translation (bilingual or monolingual), terminological, explanatory, educational or in a terminological data bank.

From the perspective of our discussion, it is first necessary to touch the problem of dictionaries' classification. The main characteristics of a special lexis unit, formal and informative features, the ability to form phrases, to single out the concepts that the terms represent are considered to be the primary bases for a dictionary typology.

It is worth noting that there are different approaches to dictionary classification, and there is still no generally accepted typology.

The first native typology was offered by L.V. Shcherba and was based on 6 oppositions: 1) dictionary of an academic type/dictionary/ reference book; 2) encyclopedia/dictionary of general lexis; 3) thesaurus/dictionary of general lexis or translation and explanatory dictionary; 4) dictionary of general lexis or translation and explanatory dictionary/ideographic dictionary; 5) explanatory dictionary/translation dictionary; 6) non-historical dictionary/ historical dictionary.
Unfortunately, the typology outlined above does not include specialized dictionaries as a separate type, but still it is worth mentioning as the authors of dictionaries' classifications later developed their proposals on the bases of criteria offered by L.V. Shcherba.

A rather detailed classification was elaborated by Z.I. Komarova, who suggested the following 11 criteria:

- number of languages used in a dictionary (monolingual, bilingual, multilingual dictionaries),

- main task of a dictionary (explanatory dictionary, translation dictionary, systemized glossary),

- type or types of industry represented in a dictionary (dictionary of general lexis, narrow branch dictionary, multi-branch dictionary),

- special purpose of a dictionary (dictionary of notions, dictionary of frequency, educational dictionary and others),

- principle of term semantization (encyclopaedic dictionary, explanatory dictionary, dictionary that does not include explanations),

- type of glossary (unabridged, medium size, brief dictionary),

- type of users (dictionary for specialists with educational qualification, for scientists, for practitioners, for university students, for college students, for school students, etc.),

- width of designation (dictionary addressed to a person, computer addressed dictionary),

- terms arrangement (alphabetically arranged dictionary, alphabetically-nested dictionary, permutational dictionary, ideographic dictionary, dictionary of opposite frequency, hierarchical dictionary),

- standardized type of usage (authority list, dictionary of standardized lexis),

- level of currency of lexis (dictionaries of new lexis, dictionary of usage, historical dictionaries). 
It should be noted that despite numerous criteria taken into consideration, the classification does not touch lists of classification headings, classifiers and reference-books.

Among numerous classifications of specialized dictionaries, it is also worth noting the one offered by V.M. Leichik, who stated that the main criteria for dictionary typology are the relevant features of dictionaries, their content and form. There are six differentiae:

- subject scope (multi-branch dictionary, branch dictionary, narrow branch dictionary),

a) information given in the left part of the entry, i.e. the headword (dictionary of terms, dictionary of term-elements),

b) information given in the right part of the entry (translation dictionary, explanatory dictionary, reference-books, list of terms ideographic and descriptive dictionary),

- way of arrangement in a dictionary (alphabetic, non-alphabetic (topical) that might be nested or alphabetic-nested, statistical alphabetic or non-alphabetic),

- purpose and function of a dictionary (dictionary of usage, regulating dictionary (normative and non-normative), science-fiction dictionary, educational dictionary, informative dictionary (informative retrieval thesaurus, classifier, lists of classification headings), systemizing dictionary dictionary of terminological system, dictionary of frequency and reverse dictionary),

- number of languages (monolingual, bilingual, multilingual),

- dictionary novelty (dictionary of new terms).

All in all, it is suggested that the dictionary typology offered by L.V. Shcherba lists the main types of dictionaries. Accordingly, the present article describes such types of specialized works as translation, explanatory and educational dictionaries, as well as encyclopaedias, referencebooks, electronic dictionaries and thesauruses.

\subsection{Dictionary description}

- Translation (bilingual and multilingual) specialized dictionary

Translation specialized dictionary should combine qualities of both translation and specialized dictionary. So such a dictionary is not only to offer a foreign language equivalent, but also to include stylistic remarks (professional lexis, archaic term), grammar remarks (part of speech), brief explanations in case of difficulties with the meaning, examples of term phrases if they exist, remarks of sub-branches (pharmacology, dentistry, surgery) where applicable, etc.

An analysis of more than 35 translation specialized bilingual (i.e. Russian- English or English-Russian) dictionaries has shown that: such dictionaries feature a rather large number of entries, but they mainly contain terms and foreign equivalents with no other comments on the choice among synonyms that are frequently listed in an entry.

The examples of translation dictionaries are numerous, some of which are: Modern English-Russian Automotive Dictionary by U.V. Ginzburg, English-Russian Ecological Dictionary edited under the supervision of Prof. G.N. Akzhigitov, Russian-English Oil-Field Dictionary by D.E. Stoliarov, etc.

\section{- Explanatory dictionary}

Explanatory terminological dictionaries reference works that describe certain set of special lexis, concepts and subjects of a special field of knowledge/science and/or technology. The main aim of explanatory dictionaries is to define the meaning of a term. As a rule, this kind of dictionary is complex as the entry does not only contain the definition, but there also might be information on spelling, pronunciation, grammar and word-building, stylistic features, encyclopaedic, etymological, historical information. While analysing this type 
of dictionaries published in Russia, it is possible to differentiate 2 major groups: monolingual explanatory dictionary of some terminology (e.g., Explanatory Terminological Dictionary. Carbonbase Material by O.E. Konstantinova; Explanatory Terminological Dictionary of Polytechnic Lexis by B. Butakov and I. Fagradyanz,) and combined explanatory translation dictionary (e.g., Russian-English and English-Russian Explanatory Dictionary of computer terms by A. Koszov, V. Koszov, Russian-English and English-Russian Dictionary of wood-sawing lexis by M.V. Kholodilova, Explanatory RussianEnglish Dictionary of Molecular and Cellular Biotechnology by V.Z. Tarantul).

Explanatory translation dictionaries mainly consist of two parts. The first, i.e. the main part, has the following structure: a term (headword), its foreign language equivalent, explanation of the notion that the term expresses, sometimes information on etymology (V.Z. Tarantul), remarks for codified and non-codified lexical units (M.V. Kholodilova). The second part is simply translative, in which the term is supplied with its foreign language equivalent.

\section{- Educational dictionary}

In lexicography, educational dictionaries are singled out as a separate kind used as a means of teaching. The educational character is expressed in the content of a glossary; the choice of lexical items, its arrangement, way of presentation; language of presentation and the number of lexical units included. Educational dictionaries have three main functions: educative, reference and normative ones.

There is a great number of educational dictionaries touching different terminological systems. Nowadays numerous works of such kind are compiled and published by institutes of higher education in Russia as an answer to current educational needs, i.e. - to form a conceptual construct in a certain discipline. It is possible to talk about different variants, such as: educational terminological dictionaries or educationaltranslative dictionaries of different disciplines. Also, the structure of such dictionaries might vary. Accordingly, an entry may include: the title of an entry (the term itself, also called a headword); information on etymology; definition; examples of term usage; pictures, graphics, etc. The number of terms included in a dictionary is connected with the aims and tasks the discipline has. Two main specific requirements for such kind of terminological dictionaries are: correspondence to the discipline curriculum and accessibility of term description for the potential user. Among the examples of educational terminographic works the following ones can be mentioned: Educational Terminological Dictionary on Philosophy and Concepts of Current Nature Study by S.V. Gribanov and I.N. Borisov; Educational Dictionary of Stylistics Terms by O.N. Laguta; Terminological Dictionary on Logopaedics and Neuropsychology by L.D. Chuprov; Educational English-Russian and Russian-English terminological Dictionary on Motor-Ways edited by T.U. Poliakova and others.

\section{- Encyclopedia}

In this type of work, the terms are followed not only by a brief definition, but also a detailed encyclopaedic description. Actually, encyclopaedic dictionaries do not define the words, but rather notions, objects, events, phenomena.

The first encyclopaedias appeared approximately at the time of Aristotle in V-IV centuries BC. But in Russia the first practice of compiling encyclopaedias, not dictionaries, was taken only in the 1870-s. I.A. Efron with his desire, financial support and ability to organise people's work, contributed to the appearance of such works as an 86-volume Encyclopaedic Dictionary (1890- 
1907), Small Encyclopaedic Dictionary (1904 and 1907), and the unfinished New Encyclopaedic Dictionary. Other works of similar type include: Encyclopaedic Dictionary by Granat brothers (1910-1948) that was characterized by rather long, detailed entries with extensive bibliography; Encyclopaedic Dictionary by F.F. Pavlenkov with 1-st edition in 1899 and the last, 5-th edition, in 1913 and 1923. All in all, multi-level system of encyclopaedic editions, consisting of different types of encyclopedias, was formed by 1917 in Russia. In general, traditionally two types of encyclopaedias are differentiated - general and specialized ones. Some examples of modern specialized encyclopaedias are: Small Medical Encyclopaedia; Big Medical Encyclopaedia; Brief Literature Encyclopaedia; The RussianEnglish Encyclopaedic Dictionary of the Arts and Artistic Crafts; Biological Encyclopedic Dictionary, etc.

\section{- Reference -books}

Reference-books in comparison to dictionaries are more narrow in the field of its coverage. They have a practical orientation, giving answers to such questions as: What? Who? Where? When? and How?

Reference books feature a systemized structure and alphabetic order of entries presentation. According to their purpose, they may be: scientific, politic, industrial and practical, educational, popular, common; while according to the data carrier they might be - paper and online.

The most widely-spread specialized reference-books are: qualifier (e.g. of plants and animals, minerals) which provides basic information in some field; and catalogs, containing information on technical features of some details or a list of existing items.

Here are some of the examples of specialized books: Reference-book of Linguistic Terms by
O.S. Akhmanova; Terminological Referencebook of Physiotherapist, by V.E. Illarionov; Terminological Reference-book of the Main Notions of Translation Studies edited by V.N. Bazylev; Terminological ReferenceBook on Psychology and Pedagogics edited by T.M. Barinova, Terminological Reference-Book on Economics, Marketing and Management edited by Petrov U.A., etc.

\section{- Electronic Dictionaries}

Computer terminography is considered to be a transitional discipline on the way from manual and handwritten lexicographic practice to new paperless informative technologies. So, in general, it is an applied discipline studying methods of using computers while compiling dictionaries that appeared in the 1950-s - 1960-s, In Russia, Yu.N. Marchuk was one of the first scholars who in the 1970-s outlined the possibilities of using the computer for educational lexicography. Yet, the peak of scientific investigations started only in the 2000-s.

Indeed, the computer can solve such tasks as maintaining the alphabetic order of all the lexical units entered and indicating the usage-frequency level. Numerous research works on computer terminography enumerate both advantages and disadvantages of electronic dictionaries. So, L.N. Beliaeva mentions the following advantages: quickening the word and word-combination search as well as the search of foreign equivalents in a detailed entry; different possibilities for entry review, maximum required information localization; possibility for quick replacement of foreign equivalents in text file by copying it to clipboard; possibility for dictionary content to be up-to-date due to frequent updates; possibility to make quick changes in a dictionary, etc. Among the disadvantages, G.R. Chumarina, for example, mentions such problems as: certain period of time is needed to learn how to use each dictionary, 
as far as interfaces differ in dictionaries; some technical difficulties for viewing the entry that can be seen only partially; the time that less experienced users need to find what they need; the necessity of having a computer; possible technical problems among other issues.

One sub-type of electronic dictionary is an on-line dictionary that has become more and more popular among the users.

At present in Russia there are three types of on-line dictionaries - genuine electronic dictionaries; traditional dictionary copycats; and mixed dictionaries that include both of the mentioned above.

Among the most prominent electronic specialized dictionaries are: monolingual (Mir Slovarey, Krugosvet, etc.), multilingual and translative (Everest Dictionary, Polyglot, Multitran, etc.), encyclopedic (Big Encyclopedic dictionary), illustrative (Polyglossum Illustrative Dictionary on Banking and Economics), terminological (Polyglossum, Polyglot, Multilex, Multitran, Multi-Dic, Informatic-Contex and other dictionaries in Physics and Mathematics, Medicine, Law, Electronics, Science, etc. in varies languages).

\section{- Thesaurus Dictionary}

Terminographic research of this type seem to be recently rather promising as they are based on corpus analyses data and allow to show its influence on the structure of dictionary entry and choice of illustrating material. In terminographic practice the main thesis is that separate corpus should be compiled for the ideal study of a certain corpus. Along with electronic corpus other primary sources form the base of a dictionary, e.g. traditional terminological cards with examples that are part of an archive. It is preferable to make the archive in an electronic way because it makes its benefit higher as the search for detailed texts by the review of different examples becomes possible.
Thesaurus lexicography mainly appeared due to compiling educational dictionaries of modern languages. As for the role of lexicography concerning different terminological systems, it still needs paying attention to. However, its role in terminography is also valuable. In this regard, while preparing new dictionaries on the basis of existing ones, system corpora usage may give a start for many lexical units to be included in a dictionary as well for some archaic to be excluded or to be marked as such. In translative terminography parallel corpora are widely used for automatic creation of dictionaries, marking terms for multilingual terminological databases; verification the meanings of terms and term units, estimation of translation adequacy.

The following works devoted to the terminographic problems of dictionary compilation can be mentioned: "Lexicographic description of English and Russian phytonims in electronic dictionaries" by N.A. Sivakova (the work isdoneonintersection ofmetaterminography, cognitive terminography, computer linguistics, corpus linguistics), "Principles of Compiling Educational Ideographic Dictionary of Building Terminology" by Abdurakhmanova A.Z. (the research deals with the terminographic framework which serves as the basis for the development of English-Russian learner's thesaurus on civil engineering and for the design of its microstructure).

While analyzing the latest Ph.D. theses it is possible to mark the following problems that are being discussed:

- Different points concerning dictionaries (the role of certain type and its place among other types; development of a new dictionary type and its structure; suggestion of a new dictionaries classification; analyses of the existing types of dictionaries; methodology of dictionary compiling and the problems connected with this work) are touched in the works of Shilenkova 
E.V., 1984; Levicheva S.V., 1999; Medvedeva I.V., 2000; Khmelevskaya I.U., 2006; Lutzheva M.V., 2008; Chumarina G.R., 2010; Uzhova O.A., 2011 and many others.

- Special attention is paid to metaterminographic options that are worth singling out separately - systemizing metaterminographic state; characteristic of lexicographic parameters; realization of main terminographic requirements while compiling dictionaries; correspondence of dictionaries to user's needs; study of modern state of computer terminography (Levicheva, 1999; Medvedeva, 2000; Lovzevich, 2010; Chumarina, 2010).

- The authors also discuss problems of material studied: choice of lexical units for further inclusion in a dictionary; description of terms; their peculiar features and different kinds of relations among them (Khmelevskaya, 2006; Lutzheva, 2008, etc.).

\section{Conclusion}

Modern Russian terminography is considered to be an independent complex discipline, and as has been mentioned above, it is comprising three areas - the history of terminography, metaterminography and practical terminography, though the history of terminology might be treated as a part of metaterminography.

The level of investigation of each of above-mentioned areas is different, while most investigated and most popular areas include practical terminography, developing much ahead of theory. Yu.N. Marchuk points out that at least one specialized dictionary is published every day in the world (Marchuk, 1992). This covers the specific areas of certain sublanguage and is to help specialists working in the field, including translators and interpreters. Unfortunately, such works are sometimes unreliable, as in most cases the scientific level of these dictionaries is rather poor. The main problem here has been voiced by S.V. Grinyov-Grinevich in his work "Introduction to terminography: How to create a dictionary" - translation orientated dictionaries are usually made by specialists in certain scientific or technical field, who have no background in lexicography. One can hardly disagree. In this connection the words of a famous French lexicographer J. Rey-Debove in the late 1970 -s seem to be valid in terminography even nowadays - the situation that terminographer faces, is worsened in two ways - on the one hand nobody knows what the lexicographic work exactly means, on the other hand - there is any interest in novelty. Thus, in spite of the fact that several decades have passed, lacunas continue to exist. Accordingly, some points still need to be discussed:

- justification of the object for the terminographic description (term, professional unit, nomenclature unit, the whole block of terminological lexis),

- principles for the choice of certain sublanguage lexis,

- development of methodological principles of compiling terminological dictionaries or dictionaries of special lexis,

- solving the problem of standardized and appropriate non-standardized units,

- identification of terminographic universals,

- investigation of macro and microstructure of terminological dictionary,

- elaboration of the rules for special units' description, including terminological phrases,

- development of main parameters for dictionaries of special and terminological lexis depending on their type,

- development of invariant dictionaries projects for the description of different sublanguages,

- solving the problems of lexicographic genres appropriate for terminography, 
- typology of dictionaries of special lexis and terminological dictionaries,

- investigation of attribution of dictionary types to lexicographic genres, etc.
The final conclusion seems to be that in spite of the fact that a number of works touching theoretical and practical aspects of terminography have been published, theory and practice still seem to be far from each other.

\section{References}

Beliaeva, L.N. (2011). Atomatizirovannaya leksikologiay: gumanitarnye tehnologii [Computeraim lexicography: humanitarian technology]. St. Petersburg: edition of Herzen RSPU. 75 p.

Bergenholtz, H., Tarp, S. (1995). Manual of Specialized Lexicography. The preparation of specialized dictionaries. Amsterdam, Philadelphia. 201 p.

Bergenholtz, H., Kaufmann, U. (1997). Terminography and lexicography. A critical survey of dictionaries from a single specialized field. Hermes. $125 \mathrm{p}$.

Borkhwaldt, O.V. (1998). Russkaya terminographiya $v$ istoricheskom aspekte [Russian terminography in historical aspect]. Krasnoyarsk. 118 p.

Chumarina, G.R. (2010). Teoria i practika sostavleniya elekrtonnyh slovarey [Theory and practice of compiling computer dictionaries]. Kazan. 199 p.

Denisov, P.N. (1974). Ocherki po russkoi leksikologii i uchebnoi leksikografii [Essays on Russian lexicography and academic lexicography]. Izdatelstvo Moskovskogo universiteta. 256 p.

Gagarin, S.N. (2000). Metodika sostavleniya uchebnyh slovarey LSP [Methodology of LSP academic dictionary compilling]. Moscow. $130 \mathrm{p}$.

Gerd, A.S. (1986). Osnovy nauchno-tehnicheskoi leksikografii [The Bases of Technical and Scientific Lexicography]. Leningrad. 72 p.

Grinyov-Grinevich, S.V. (2009). Vvedenie v terminografiu [Introduction to terminography]. Moskva: Knizhny dom «Librokom». 224 p.

Kholodilova, M.V. (2009). Russko-angliyskiy i anglo-russkiy slovar' lexiki lesopilnoy promyshlennosty [Russian-English and English-Russian dictionary of wood-sawing lexis]. Krasnoyarsk, Krasnoyarsk state pedagogical university after V.P. Astafiev. 200 p.

Komarova, Z.I. (2016). Kogda I pochemu voznikla terminographiya kak nauchnaya disciplina? [When and Why Did Terminography as as Applied Science Appear?]. In Aktualnye problemy germanistiki, romanistiki i russistiki, 3 (3), 90-107.

Kudashev, I. (2007). Proektirovanie pervodcheskih slovarei specialnoi leksiki [Designing LSP Dictionaries for Translators]. Helsinki University print, Helsinki. 445 p.

Lukasik, M. (2016). A short history of Polish-Ukrainian Terminography. In Cognitive Studies, 16, 65-89. Available at: https://doi.org/10.11649/cs.2016.007

Lukasik, M. (2017). Contrastive Terminography. Cognitive Studies. In Études Cognitives, 17, 1-14. Available at: https://doi.org/10.11649/cs.1378

Lutzeva, M.V. (2008). Leksikographicheskoe opisanie uridicheskoy terminologii [Lexicographic description of law terminology]. Ivanovo, 2008. 279 p.

Marchuk, Yu.N. (1992). Osnovy termonografi [The basis of terminography]. Moscow, 75 p.

Shaikevich, A.Y. (1983). Problemy terminologicheskoy leksikografii [The problems of LSP lexicography]. Moskva. $71 \mathrm{p}$. 
Taranova, E.N. (2011). Problematika sovremennogo teoreticheskogo terminovedeniya. Dostizheniya i nedostatki terminologicheskih issledovaniy [The problems of modern theoretical terminography. Achievements and drawbacks of terminological surveys]. In Nauchnye vedomosty. Seriya Gumanitarnye nauki, 24 (119), 142-149.

Trossel, M.V. (2015). Leksika russkoy i angliyskoy lesopilnoy promyshlennosty: poliparadigmalniy podhod [Russian and English language lexis of wood-sawing industry: poly-paradigm approach]. Krasnoyarsk, SFU. 204 p.

\section{Практика метатерминографических исследований в России}

М.В. Троссель

Сибирский федеральный университет Россия, 660041, Красноярск, пр. Свободный, 79

Современная терминография в России представляет собой отдельную сложную дисииплину, включающую в себя историю терминографии, метатерминографию (теоретическую терминографию), практическую терминографию. Основной особенностью терминографии является не только значимость практической работы по составлению словарей специальной лексики, но и тот факт, что терминография в большей степени по сравнению с другими дисииплинами обнаруживает связь с различными научными направлениями и отраслями производства. В данной статье рассматривается терминография, включая ее предмет и иели исследования, а также работы российских авторов в области метатерминографии.

Ключевые слова: терминография, метатерминография, лексикография, терминологическая лексикография, словарь.

Научная специальность: 10.02.00 - лингвистика. 